\title{
Psychometric Validation of Hindi Version of 2018 Lake Louise Acute Mountain Sickness Scoring System
}

\section{Deepak Dass, Thinles Chosphel, Harish Kumar}

\author{
Defence lnstitute of Physiology and Allied Sciences, DRDO, Lucknow Road, Timarpur, Delhi - 110054.
}

\section{ABSTRACT}

Background: The Lake Louise Score (LLS) - 2018 is a revised 4-item questionnaire used in the diagnosis of Acute Mountain Sickness. However, a validated Hindi translation of LLS-2018 is not available.

Material and Method: Fifty Hindi-speaking volunteers self-reported the translated Hindi version of LLS- 2018 after active ascent to high altitude $(11,500 \mathrm{ft})$. It was then tested for its face validity and internal consistency.

Result: The Cronbach's alpha was 0.69 and the corrected item score correlation was greater than 0.3.

Conclusion: The simple psychometric properties validate the Hindi version of LLS-2018 for the diagnosis of Acute Mountain Sickness.

Key Words: Acute Mountain Sickness, Lake Louise Score, Hindi translation, Psychometric

\section{INTRODUCTION}

Acute mountain sickness (AMS) is prevalent in mostly inadequately acclimatized individuals ascending to above 2500 $\mathrm{m}(8000 \mathrm{ft})$ altitude $^{1}$. It is characterized by a combination of nonspecific symptoms, i.e. headache, fatigue, dizziness, loss of appetite and nausea ${ }^{2}$.

Lake Louise Score (LLS) is the most frequently used selfreporting questionnaire used in the diagnosis of $\mathrm{AMS}^{3}$. It was previously based on five symptoms namely headache, gastrointestinal symptoms, fatigue, dizziness and insomnia ${ }^{4}$. The symptoms were rated on a scale from 0 to 3 where 0 represents the absence of a symptom and 3 represents a severe symptom $^{5}$.The LLS Consensus Committee revised his in 2018 (LLS18), wherein sleep disturbance was removed as a symptom for diagnosis ${ }^{6}$. In the revised system Acute Mountain Sickness is diagnosed if the LLS18score total exceeds 3 points from the four rated symptoms, including atleast one point from headache ${ }^{6}$. English is the source language of LLS18.
Direct application of English version of self-reporting questionnaires, as this one, without adapting to the cultural context or employing poorly translated versions can adversely affect the diagnostic effectiveness and validity of research data?

Dellasante et $\mathrm{al}^{8}$ pointed out the importance of language when assessing altitude illness, strongly recommending translations of AMS questionnaires to the target language and psychometric validation of the translation to avoid deviation of meaning during translation.

There are approximately more than three hundred thousand domestic travelers going to Leh, annually ${ }^{9}$. Even though the demographics are not available, the authors have arbitrarily observed that most of them are from Hindi-speaking regions of India. Every year thousands of worshippers from all over India travel to Shri Amarnath Yatra (12,700 ft); Hemkund Sahib (14,000 ft); Manasarovar, $(14,700 \mathrm{~m})^{10}$. Pilgrims traveling to high altitude are a vulnerable group ${ }^{11}$. There is general lack of awareness about AMS its prevention and usage of LLS as a diagnostic tool among these pilgrims ${ }^{12}$. A translated

Corresponding Author:

Deepak Dass, Defence Institute of Physiology and Allied Sciences, DRDO, Lucknow Road, Timarpur, Delhi - 110054. Phone: +91 11 23883108; Email: deepakdas@dipas.drdo.in

ISSN: 2231-2196 (Print)

Received: 22.07 .2019
ISSN: $0975-5241$ (Online)

Revised: 18.08 .2019
Accepted: 10.09 .2019 
version of the LLS in Hindi could be helpful in the early detection of AMS. Early recognition of AMS is key to allowing individuals to seek medical attention before the risks of complications increases ${ }^{13}$.

Therefore, the aim of this study was to translate a conceptual equivalent of the LLS18 in Hindi (Devangari script), (LLS18H), and conduct a post hoc psychometric validation.

\section{METHOD}

The LLS18H was translated in Hindi by the authors. Effort was made to create a conceptual equivalent that was colloquial and easy to understand. To confirm linguistic validity the LLS18H was back translated to English by a bilingual scholar from the humanities field who had no knowledge about the LLS18. The back translation was an iteratively process and each version was compared with the original English version to detect any misinterpretation or inaccuracies in the translation. The final version of the LLS18H was put up to an expert panel for evaluation in terms of comprehension and relevance of the scale's items to the concept of interest ${ }^{14}$. The expert panel consisted of three Hindi-speaking senior scientists experienced in field of high-altitude physiology. After evaluation by the expert panel, the final version of the LLS18H was frozen for validation. [Appendix - 1]

Fifty healthy Indian males volunteered for the study. The mother tongue of the volunteers was Hindi. All the volunteers had their formal education in Hindi medium. The volunteers were non-smokers, and did not have any history of pulmonary disease. The volunteers and had not visited high altitude (HA) areas in the past six months. They air travelled to the location, which is at an altitude of approximately $11,500 \mathrm{ft}$. The LLS18H was filled by them within $24-48$ hours on arrival to $\mathrm{HA}^{2}$.

Since the primary aim was to translate the LLS18 in Hindi and validate the version, two simple psychometric tests; namely face validity and internal consistency were considered to validate the LLS18H ${ }^{14}$.

Face validity is subjective assessment, defined as experts opinion and feedback from the volunteers to assess the readability, consistency of style and clarity of languageof the questionnaire items ${ }^{15}$. There no standards with regards to its measurement or quantification of face validity ${ }^{16}$. Two main facets of the translated version were assessed; comprehensibility andclarity of language. Comprehensibility was assessed by asking; "Were you able to understand the questions? [Yes/No]", clarity of language was assessed by asking "Were you able to identify the symptoms clearly [Yes/No]". The expert panel were asked to rate if the language used in the final version of the LLS18H clearly described the symptoms of AMS as "clearly represented," "somewhat represented," or "not represented."
These questions were considered to provide adequate information on the general readability, comprehensibilityand possible future review for ambiguity in the language.

The internal consistency of the LLS18H was assessed using Cronbach's alpha. A robust internal consistency was considered as value above $0.7^{17,18}$

The internal consistency is defined as the degree to which all items in the scale measures the same concept or construct and hence it is connected to the inter-relatedness of the items within the scale, it is expressed as a number between 0 and $1^{19}$. Internal consistency is the degree of the association between the items of the questionnaire items, and it can demonstrate the degree to which items are measuring the same condition $^{18}$.

A total corrected item-score correlation which avoids the inclusion of the item itself in the total was used to assess the internal validity ${ }^{20}$.

\section{RESULT}

The mean age of the volunteers was 32.5 years $( \pm 6.3)$. All the fifty volunteers were assessed with the LLS18H. Upon arrival at $11,500 \mathrm{ft}$ the mean LLS18H score was $3.21 \pm 2.04$. AMS was diagnosed for score of three or more points from the four rated symptoms, including at least one point from headache. $18 \%$ was diagnosed with AMS. All of the participants responded affirmatively to the questions with regard to comprehensibility and clarity of language.

The Cronbach's alpha score was 0.69 in this dataset. The corrected item-total correlation (Spearman Coefficient) was as follows:

\section{Table 1: Corrected Item-total Correlation of the items in LLSH18}

\begin{tabular}{lc} 
Item & Corrected item-total correlation \\
Headache & 0.623 \\
Fatigue/tiredness & 0.552 \\
Nausea and vomiting & 0.374 \\
Dizziness & 0.323 \\
\hline
\end{tabular}

\section{DISCUSSION}

General observation: The authors have observed some interviewers' inability to precisely interpret the symptoms listed in the English version of the LLS when verbally administered. The authors had also noticed a few dissimilar versions of LLS translated in Hindi being used for both diagnostic as well as research purposes. The direct application of the English version of LLS18 or informal translations could conceivably affect the diagnosis of AMS. Further, Southard et 
$\mathrm{al}^{21}$ reported the sophistication of language used in the English version LLS when applied to children and adolescent in Denver, Colorado. To our knowledge there is no validated translation of LLS18 in Hindi.

Discussion of Result: Face validity is a subjective evaluation of the questionnaire in terms of feasibility, readability, clarity of the wording, the possibility of the target audience's ability to answer the questions ${ }^{22}$. The experts panel agreed on clarity of language used to represent the symptoms of AMS in the LLS18H. Volunteers reportedly did not face any difficulty in comprehending the questionnaire and there was no ambiguity in identifying the symptoms given in the LLS18H.

Corrected item-total correlation coefficients indicate the correlation of an item with the total scale when that item is removed. Values of over 0.3 show a good level of correlation $^{23}$. All of the total corrected LLS18H items scored were the above the yardstick level of 0.30 hence supporting the internal reliability of the LLS18H. Headache gave the best item-LLS18H correlation. The fact that the LLS18H was evaluated within 24-48 hours increased the probability of occurrence of the symptom ${ }^{2}$.

The most common way to test the reliability of a translated questionnaire is to use Cronbach's alpha coefficient which was estimated to be 0.69 , signifying an adequately judicious internal consistency ${ }^{24}$. The value is similar to earlier studies conducted by Carod-Artal et al ${ }^{25}$ (Spanish version of LLS) and Macinnis et $\mathrm{al}^{26}$ (Nepali version of LLS), although the later had reported internal consistency in ordinal alpha coefficient. Therefore, the internal consistency of the LLS18H seems acceptable to assess AMS.

Limitation: The limitation of our study is that, due to small sample size the factorial structure to assess the interactions between latent factors could not be done ${ }^{27}$. The literacy status of the volunteers was not taken into consideration. The sensitivity and specificity of the translated version could not be corroborated with clinical findings.

\section{CONCLUSION}

LLS18H displayed an acceptable reliability and validity when used by Hindi-speaking volunteers. The study contributes to the usage of a validated instrument to assess the symptoms of AMS in Hindi-speaking population for diagnostic and research purposes.

\section{REFERENCES}

1. Honigman B, Theis MK, Koziol-McLain J, Roach R, Yip R, Houston C, Moore LG, Pearce P. Acute mountain sickness in a general tourist population at moderate altitudes. Ann Intern Med 1994;15;120(8):698. DOI: 10.7326/0003-4819-118-8199304150-00003
2. Gallagher SA, Hackett PH. High-altitude illness. Emerg Med Clin North Am. 2004 May;22(2):329-55, viii. DOI: 10.1016/j. emc.2004.02.001

3. Van Roo JD, Lazio MP, Pesce C, Malik S, Courtney DM. Visual analog scale (VAS) for assessment of acute mountain sickness (AMS) on Aconcagua. Wilderness Environ Med. 2011;22(1):714. DOI: $10.1016 /$ j.wem.2010.10.002.

4. Roach RC, Bartsch P, Hackett PH, and Oelz O. The Lake Louise Acute Mountain Sickness Scoring System. In: Hypoxia and Molecular Medicine. JR Sutton, CS Houston, G Coates, eds. Queen City Press, Burlington, VT.1993. pp 272-274

5. Kayser B, Aliverti A, Pellegrino R, Dellaca R, Quaranta M, Pompilio P, Miserocchi G, Cogo A. Comparison of a visual analogue scale and Lake Louise symptom scores for acute mountain sickness. High Alt Med Biol. 2010;11(1):69-72. DOI: 10.1089/ ham.2009.1046.

6. Roach RC, Hackett PH, Oelz O, Bärtsch P, Luks AM, MacInnis MJ, Baillie JK; Lake Louise AMS Score Consensus Committee. The 2018 Lake Louise Acute Mountain Sickness Score. High Alt Med Biol. 2018;19(1):4-6. DOI: 10.1089/ham.2017.0164. Epub 2018 Mar 13.

7. Wild D, Grove A, Martin M, Eremenco S, McElroy S, VerjeeLorenz A, Erikson P; ISPOR Task Force for Translation and Cultural Adaptation. Principles of Good Practice for the Translation and Cultural Adaptation Process for Patient-Reported Outcomes (PRO) Measures: report of the ISPOR Task Force for Translation and Cultural Adaptation. Value Health. 2005;8(2):94-104. DOI: 10.1111/j.1524-4733.2005.04054.x

8. Dellasanta P, Gaillard S, Loutan L, Kayser B. Comparing questionnaires for the assessment of acute mountain sickness. High Alt Med Biol. 2007;8(3):184-91. DOI: 10.1089/ham.2007.8305

9. Vladmiro P Turnover of the booming tourism industry in Leh District. In: Gutschow K, editor International Association of Ladakhi Studies, Stawa Publications; 2013, p. 6-12.

10. Basnyat B. High Altitude Pilgrimage Medicine. High Alt Med Biol. 2014 Dec 1; 15(4): 434-39.doi: 10.1089/ham.2014.1088

11. Bhandari SS, Koirala P. Health of High Altitude Pilgrims: A Neglected Topic. Wilderness Environ Med. 2017;28(3):275-77. doi: 10.1016/j.wem.2017.04.008.

12. Sahota IS, Panwar NS. A pilot study on the prevalence of Acute Mountain Sickness at the Sikh pilgrimage of Hemkund Sahib in the Indian Himalayas Indian J Occup Environ Med. 2013; 17(1): 12-15.doi: 10.4103/0019-5278.116366

13. Hofmeyr, R., Tölken G., De Decker R. Acute high-altitude illness. South African Medical Journal 2017;107(7):556-561. DOI:10.7196/SAMJ.2017.v107i7.12612

14. Streiner, DL, \& Norman, GR. Health measurement scales: A practical guide to their development and use. Oxford: Oxford University Press. 1995

15. Turner SP The concept of face validity Qual Quant February 1979; 13(1):85-90.https://doi.org/10.1007/BF00222826

16. De Vet HC, Terwee CB, Mokkink LB, Knol DL. Measurement in medicine: a practical guide: Cambridge University Press; 2011.

17. Keith ST The Use of Cronbach's Alpha When Developing and Reporting Research Instruments in Science Education Res Sci Educ 2018;48:1273-96DOI 10.1007/s11165-016-9602-2

18. Nunnally, JC. Psychometric theory (2nd ed.). New York: McGraw-Hill 1978.

19. Mohsen T, Reg D Making sense of Cronbach's alpha International Journal of Medical Education. 2011;2:53-55 doi: 10.5116/ ijme. $4 \mathrm{dfb} .8 \mathrm{dfd}$

20. Ware JE Jr., Gandek B. Methods for testing data quality, scaling assumptions, and reliability: the IQOLA Project approach. International Quality of Life Assessment. Journal of clinical 
epidemiology. 1998;51(11):945-52. https://doi.org/10.1016/ S0895-4356(98)00085-7

21. Southard A, Niermeyer S, Yaron M. Language used in Lake Louise Scoring System underestimates symptoms of acute mountain sickness in 4- to 11-year-old children. High Alt Med Biol. 2007;8(2):124-30. DOI: 10.1089/ham.2006.1014

22. DeVon HA, Block ME, Moyle-Wright P, Ernst DM, Hayden SJ, Lazzara DJ, Savoy SM, Kostas-Polston E. A psychometric Toolbox for testing Validity and Reliability. Journal of Nursing scholarship, 2007;39 (2), 155-64. DOI: 10.1111/j.15475069.2007.00161.x

23. Cristobal, E., Flavián, C., Guinalíu, M. Perceived e-service quality (PeSQ): measurement validation and effects on consumer satisfaction and web site loyalty. Managing Service Quality, 2007;17(3), 317-40. http://dx.doi. org/10.1108/09604520710744326.
24. Lance CE, Butts MM, Michels LC. The Sources of Four Commonly Reported Cutoff Criteria What Did They Really Say? Organizational Research Methods 2006; 9 (2), 202-20 DOI 10.1177/1094428105284919

25. Carod-Artal FJ, Ezpeleta Echávarri D, Guerrero Peral AL. Metric properties of the Spanish version of the Lake Louise Acute Mountain Sickness Questionnaire. Neurologia. 2011;26(6):33742. doi: 10.1016/j.nrl.2010.12.014

26. Macinnis MJ1, Lanting SC, Rupert JL, Koehle MS. Is poor sleep quality at high altitude separate from acute mountain sickness? Factor structure and internal consistency of the Lake Louise Score Questionnaire. High Alt Med Biol. 2013;14(4):334-7. doi: 10.1089/ham.2013.1030.

27. Yong AG, Pearce, S. A Beginner's Guide to Factor Analysis: Focusing on Exploratory Factor Analysis Tutorials in Quantitative Methods for Psychology 2013;9(2):79-94. DOI: 10.20982/ tqmp.09.2.p079

Appendix - 1

\section{लेक लुईस ए.एम.एस.स्कोरिंग प्रणाली वर्कशीट -2018}

\begin{tabular}{|c|c|c|}
\hline \multirow[t]{4}{*}{ सिरदर्द } & कोई सिरदर्द नहीं & 0 \\
\hline & हल्का सा सिरदर्द & 1 \\
\hline & मध्यम सिरदर्द & 2 \\
\hline & बहुत ज्यादा सिरदर्द, असहनीय & 3 \\
\hline \multirow{4}{*}{$\begin{array}{l}\text { पेट के लक्षण (उलटी आना / जी } \\
\text { मिचलाना /भूख न लगना) }\end{array}$} & भोजन के लिए अच्छी रूचि & 0 \\
\hline & जी मिचलाना और भूख न लगना & 1 \\
\hline & $\begin{array}{l}\text { मध्यम जी मिचलाना /उलटी होना या होने की संभावना } \\
\text { होना }\end{array}$ & 2 \\
\hline & बहुत ज्यादा उलटी होना , असहनीय & 3 \\
\hline \multirow[t]{4}{*}{ थकान या कमजोरी } & थकावट नहीं & 0 \\
\hline & हल्की थकान या कमजोरी & 1 \\
\hline & मध्यम थकान या कमजोरी & 2 \\
\hline & बहुत ज्यादा थकान या कमजोरी & 3 \\
\hline \multirow[t]{4}{*}{ चक्कर आना } & चक्कर नहीं आना & 0 \\
\hline & हल्का चक्कर आना & 1 \\
\hline & मध्यम चक्कर आना & 2 \\
\hline & बहुत ज्यादा चक्कर आना, असहनीय & 3 \\
\hline
\end{tabular}




\section{Lake Louise Acute Mountain Sickness Score ${ }^{6}$}

\begin{tabular}{|l|l|r|}
\hline Headache & None at all & 0 \\
\cline { 2 - 3 } & A mild headache & 1 \\
\cline { 2 - 3 } & Moderate headache & 2 \\
\cline { 2 - 3 } & Severe headache, incapacitating & 3 \\
\hline Gastrointestinal symptoms & Good appetite & 0 \\
\cline { 2 - 3 } & Poor appetite or nausea & 1 \\
\cline { 2 - 3 } & Moderate nausea or vomiting & 2 \\
\cline { 2 - 3 } & Severe nausea and vomiting, incapacitating & 3 \\
\hline \multirow{5}{*}{ Fatigue and/or weakness } & Not tired or weak & 0 \\
\cline { 2 - 3 } & Mild fatigue/weakness & 1 \\
\cline { 2 - 3 } & Moderate fatigue/weakness & 2 \\
\cline { 2 - 3 } & Severe fatigue/weakness, incapacitating & 0 \\
\hline & No dizziness/light-headedness & 1 \\
\cline { 2 - 3 } & Mild dizziness/light-headedness & 3 \\
\cline { 2 - 3 } & Moderate dizziness/light-headedness & \\
\cline { 2 - 3 } & Severe dizziness/light-headedness, & \\
& incapacitating & \\
\hline
\end{tabular}

